\title{
BINGKAI KRISIS QZ8501 PADA PRESS RELEASE AIRASIA INDONESIA YANG DIMUAT DALAM SITUS WEBSITE WWW.QZ8501.AIRASIA.COM
}

\author{
Sofian Aris S., Theresia Intan P.H., Brigitta Revia S.F. \\ Universitas Katolik Widya Mandala Surabaya \\ J1. Dinoyo 42-44 Surabaya, 60265 \\ Email : sofian.aris007@gmail.com, theresiaintan@ukwms.ac.id, gita.fiesta@gmail.com
}

\begin{abstract}
ABSTRAK
Penelitian dengan judul "Bingkai Krisis QZ8501 pada Press Release AirAsia Indonesia Yang Dimuat Dalam Situs Website www.qz8501.airasia.com", bertujuan untuk mengetahui bagaimana pembingkaian krisis QZ8501 yang dilakukan oleh maskapai penerbangan AirAsia Indonesia pada berbagai siaran press release pasca kecelakaan pesawat penerbangan QZ8501. Dalam penelitian ini, peneliti menggunakan model analisis framing menurut Robert Entman guna melihat bagaimana pihak maskapai penerbangan AirAsia Indonesia menyeleksi dan menonjolkan aspek tertentu dari suatu isu, terkait dengan krisis akibat kecelakaan pesawat QZ8501. Melalui analisa framing Robert Entman, peneliti menemukan satu frame besar, yakni krisis QZ8501 dianggap sebagai musibah yang menimpa maskapai penerbangan AirAsia Indonesia. Dimana selain digunakan sebagai suatu pijakan yang mendasari berbagai penulisan siaran press release, frame krisis tersebut juga digunakan oleh maskapai penerbangan AirAsia Indonesia sebagai suatu strategi perbaikan citra untuk mengatasi berbagai pemberitaan negatif yang muncul di berbagai media massa. Sehingga melalui penjelasan tersebut dapat terlihat jelas bagaimana fungsi dari press release yang digunakan sebagai alat untuk mengalihkan perhatian publik dari berbagai fakta yang merugikan organisasi dan memusatkan pada berbagai fakta yang menguntungkan organisasi.
\end{abstract}

Kata Kunci: Framing Public Relations, Press Release, Krisis Kecelakaan Pesawat QZ8501

\begin{abstract}
Research entitled "Bingkai Krisis QZ8501 pada Press Release AirAsia Indonesia Yang Dimuat Dalam Situs Website www.qz8501.airasia.com”, is to figure out how the QZ8501 crisis framing conducted by AirAsia Indonesia airlines in various flight press release after QZ8501 airplanes crash. In this study, the researchers used the framing analysis model according to Robert Entman to see how the AirAsia Indonesia management selected and highlighted certain aspects of an issue, related to the crisis due to QZ8501 aircraft crash. Through Robert Entman's framing analysis, researchers found a large frame, the crisis QZ8501 considered as a disaster that befell AirAsia Indonesia airlines. In addition, being used as a foothold underlying various press release announcement, the frame of crisis is also used by AirAsia Indonesia airlines as a good image enhancement strategy to overcome various negative news that appears in many mass media. So through that explanation, it became crystal clear how the function of the press release is used as a tool to divert public attention from the facts that harm the organization and then focus on the facts that benefit the organization.
\end{abstract}

Keywords: Framing Public Relations, Press Release, Aircraft Crash Crisis QZ8501

\section{PENDAHULUAN}

Pada akhir bulan Desember tiga tahun yang lalu, tepatnya pada tanggal 28 Desember 2014, terjadi sebuah kecelakaan pesawat milik maskapai penerbangan AirAsia Indonesia dengan nomor penerbangan QZ8501. Lebih jelasnya, pesawat QZ8501 merupakan pesawat yang memiliki rute penerbangan Surabaya menuju Singapura. Berdasarkan informasi yang didapat pesawat QZ8501 dan dinyatakan hilang dan jatuh di Selat Karimata dekat Pangkalan Bun, Kalimantan Tengah pada Minggu dini hari. Dalam penerbangannya tersebut, pesawat QZ8501 membawa total sebanyak 155 penumpang, dengan rincian sebagai berikut: 137 penumpang adalah orang dewasa, 17 penumpang adalah anak-anak dan 1 bayi, serta terdapat 2 pilot, 4 awak kabin dan satu 
teknisi (Jati, 2015 dalam cnnindonesia.com, diakses 20 November 2017).

\section{Menurut Hull \& Marchinery}

Insurance (akademiasuransi.org), kecelakaan pada alat transportasi dapat dibagi kedalam dua kategori, yakni: actual total loss dan constructive total loss. Dalam pengertiannya, actual total loss merupakan kecelakaan yang menyebabkan alat transportasi tidak dapat diselamatkan, hancur (destroyed), atau hilang bersama dengan muatannya, sedangkan constructive total loss merupakan kecelakaan yang menyebabkan alat transportasi masih dapat diselamatkan, namun biaya perbaikan lebih besar dari nilai alat transportasi atau harga asuransi alat transportasi. Sehingga kecelakaan pesawat yang dialami oleh maskapai penerbangan AirAsia Indonesia pada penerbangan QZ8501 tersebut dapat dikategorikan kedalam kategori kecelakaan pesawat yang bersifat actual total loss.

Mendapati kecelakaan pesawat yang bersifat actual total loss tersebut, tentu banyak pihak yang merasa terpukul dan merasa berduka. Salah satunya adalah pihak dari keluarga dan kerabat penumpang. Dimana dalam kasus kecelakaan pesawat QZ8501 tersebut, banyak dari pihak keluarga dan kerabat penumpang yang merasa histeris maupun pingsan selama mengikuti kabar tentang hilangnya pesawat dengan tujuan Surabaya menuju Singapura itu (Maharani, 2014 dalam kompas.com, diakses 20 November 2017).
Terlepas dari berbagai gejala negatif yang menimpa kondisi psikis dan fisik keluarga dan kerabat penumpang, sebagai maskapai penerbangan yang melakukan penerbangan pada pesawat QZ8501 tersebut, pihak maskapai penerbangan AirAsia Indonesia juga mengalami berbagai kerugian, baik kerugian yang bersifat material maupun kerugian yang bersifat non-material (immaterial) atas imbas dari kecelakaan jatuh dan hilangnya pesawat QZ8501. Dimana seperti yang ditulis oleh The Strait Times pada laman Firstpost.com, pihak maskapai penerbangan AirAsia Indonesia mengalami penurunan saham sebanyak $10,34 \%$ yang awalnya $12,9 \%$ menjadi $2,56 \%$.

"Saham maskapai penerbangan AirAsia Indonesia terjun dari 12,9\% menjadi 2,56\% Ringgit Malaysia. Hal ini merupakan titik terendah sejak 28 November lalu." Sumber: Pratomo, 2014 dalam www.merdeka.com Selasa, 30 Desember 2014, diakses pada 20 November 2017.

Selain mendapati penurunan saham tersebut, maskapai penerbangan AirAsia Indonesia juga mendapatkan teguran (sanksi) berupa penutupan sementara (pembekuan) atas penerbangan dengan rute Surabaya menuju Singapura. Penutupan tersebut dilakukan lantaran, maskapai penerbangan AirAsia Indonesia telah melakukan pelanggaran pada jam izin penerbangan QZ8501. Dimana seharusnya penerbangan dengan rute Surabaya menuju Singapura hanya dapat dilakukan pada hari Senin, 
Selasa, Kamis, dan Sabtu, sesuai dengan rumus 1-2-4-6. Namun, pesawat milik maskapai penerbangan AirAsia Indonesia dengan nomor penerbangan QZ8501 melakukan penerbangan dengan rute Surabaya menuju Singapura pada hari Minggu, 28 Desember 2014 (www.bbc.com, diakses pada 20 November 2017).

Menanggapi berbagai kerugian yang bersifat material dan non-material (immaterial) atas dampak dari kecelakaan jatuh dan hilangnya pesawat QZ8501 tersebut, membuat pihak maskapai penerbangan AirAsia Indonesia memilih serta menerapkan sarana publisitas guna untuk mendapatkan pemberitaan positif di berbagai media massa serta memberikan informasi kepada publik secara luas. Dimana dalam hal ini, maskapai penerbangan AirAsia Indonesia melakukan dan menerapkan sarana publisitas melalui tulisan dengan cara menyebarkan press release (immediate release) secara luas yang dapat dilihat dan diunduh pada situs resmi website www.qz8501.airasia.com.

Penelitian ini memiliki beberapa poin penting dibanding penelitian sebelumnya yang meneliti mengenai pemberitaan kecelakaan pesawat di Indonesia. Penelitian yang dilakukan Purnama, F. Y., Nugraheni, Y., \& Andreas, S. (2016: 62-67) meneliti pemberitaan kecelakaan AirAsia QZ8501 pada SKH Jawa Pos dan KOMPAS. Penelitian tersebut menggunakan perspektif jurnalistik dengan metode analisis isi. Yang khas dari penelitian ini adalah menggunakan perspektif public relations dengan metode kualitatif (analisis framing) dengan menggunakan press release di media online sebagai subjek penelitian.

Menurut Kriyantono (2008:146), press release atau news release adalah sebuah berita atau informasi yang disusun oleh sebuah organisasi (public relations) yang memiliki fungsi sebagai wahana informasi tentang kegiatan perusahaan yang dikirim ke media, dengan maksud agar informasi yang ada dalam press release tersebut dimuat dalam bentuk berita oleh berbagai media. Sebagai produk hasil karya dari public relations (Kriyantono, 2014:317), seperti: jargon, event, artefak, dan berbagai produk tulisan, khususnya press release tidak akan terlepas dari aktivitas yang disebut framing (pembingkaian).

Pada dasarnya, analisa framing (Eriyanto, 2002:3) dapat digambarkan sebagai analisis untuk mengetahui bagaimana realitas (peristiwa, aktor, kelompok, atau siapa saja) dibingkai oleh media. Pembingkaian tersebut tentu melalui proses konstruksi, dimana realitas sosial dimaknai dan dikonstruksi dengan makna tertentu. Mengadopsi pemikiran tentang konstruksi sosial tersebut, public relations pada dasarnya juga melakukan aktivitas yang sama, yakni mengkonstruksi suatu realitas sosial dengan cara memengaruhi persepsi publik dalam 
mendefinisikan realitas (Kriyantono, 2014:314).

Dalam melakukan konstruksi atas realitas sosial, public relations memiliki fungsi untuk menciptakan frame organisasi yang dapat memengaruhi frame publik (Kriyantono, 2014:315). Dimana melalui fungsi tersebut, diharapkan persepsi publik terhadap realitas, seperti: krisis, isu, atau kebijakan yang dilakukan organisasi dapat bersifat positif atau tidak bertentangan dengan persepsi organisasi atau perusahaan. Sehingga dengan adanya kesamaan (homofili) persepsi tersebut akan mendukung terciptanya proses komunikasi yang efektif. Selain itu, melalui framing, public relations dapat membantu organisasi atau perusahaan untuk mendefinisikan realitas dengan cara membangun bingkai berpikir (frame of reference) tentang isu yang menjadi perhatian (Prastya, 2016:195).

Berkaitan dengan perspektif framing dalam public relations, Hallahan (dalam Kriyantono 2014:318-320) menemukan bahwa, terdapat tujuh model framing agar seorang public relations dapat mem-framing atau mengkonstruksi suatu realitas yang ada, antara lain: framing situasi, framing atribusi, framing pilihan, framing tindakan, framing isu, framing tanggung jawab, dan framing berita. Dimana ketujuh model framing tersebut memiliki karateristik yang berbedabeda dalam memberikan penonjolan maupun angle saat membingkai suatu peristiwa atau realitas.

Menurut Hallahan (dalam Kriyantono, 2014:312, pada dasarnya terdapat tiga tahapan penting yang terjadi dalam suatu framing, pertama yakni inklusi (inclusion), kedua eksklusi (exclusion), dan ketiga penekanan (emphasis). Inklusi (inclusion) merupakan proses memilih peristiwa, kata, gambar, atau foto-foto untuk disampaikan kepada orang lain. Eklusi (exclusion) adalah proses untuk tidak menyampaikan (mengabaikan) suatu peristiwa, kata, gambar, atau foto. Sedangkan, penekanan (emphasis) dilakukan untuk mendapatkan efek pesan yang tinggi, seperti suatu pesan yang diulang-ulang atau foto yang dicetak dalam ukuran yang besar, pemberian garis bawah pada suatu kata. Sehingga merujuk pada tiga proses tersebut, dapat dikatakan bahwa framing akan membatasi atau mendefinisikan makna pada diri seseorang.

Berkaitan dengan berbagai penjelasan framing diatas, dapat dijelaskan bahwa maskapai penerbangan AirAsia Indonesia memilih sarana publisitas tulisan melalui penulisan press release yang dimuat dalam situs resmi website www.qz8501.airasia.com guna untuk menjadi alat dan sarana pembingkaian (frame) krisis kecelakaan jatuh dan hilangnya pesawat QZ8501. Melalui press release tersebut, maskapai penerbangan AirAsia Indonesia ingin membingkai krisis yang sedemikian rupa agar tercipta frame 
organisasi yang dapat memengaruhi frame publik.

Sehingga berdasarkan berbagai penjabaran dan uraian latar belakang diatas, adapun rumusan masalah yang peneliti ingin ketahui dan temukan adalah bagaimana bingkai krisis QZ8501 pada penulisan press release AirAsia Indonesia yang dimuat dalam situs website www.qz8501.airasia.com. Sejalan dengan hal tersebut, peneliti memilih model framing Entman sebagai metode analisis framing. Model framing tersebut dipilih karena dalam dalam konsepsi Entman (Eriyanto, 2002:188), framing terbagi kedalam empat sturktur, yakni: define problems, diagnose causes, make moral judgement, serta treatment recommendation yang pada dasarnya merujuk pada pemberian definisi, penjelasan, evaluasi, dan rekomendasi dalam suatu wacana untuk menekankan kerangka berpikir tertentu terhadap peristiwa yang diwacanakan. Sehingga melalui konsepsi framing Entman tersebut, peneliti dapat melihat bagaimana krisis dilihat, siapa penyebab krisis tersebut, penyelesaian apa yang ditawarkan dalam krisis tersebut, dan nilai moral apakah yang disajikan untuk menjelaskan masalah atau krisis dalam press release.

\section{TINJAUAN PUSTAKA}

Pada dasarnya, tidak hanya media saja yang dapat melakukan aktivitas pembingkaian (framing). Namun, perusahaan atau korporasi pun dapat melakukan aktivitas pembingkaian yang serupa. Dimana dalam sebuah perusahaan atau organisasi public relations (Kriyantono, 2014:314) memiliki fungsi dan peran untuk memengaruhi persepsi publik dalam mendefinisikan suatu realitas. Dimana dalam menjalankan fungsi tersebut, public relations menggunakan berbagai macam framing (pembingkaian) guana untuk menciptakan persepsi publik terhadap realitas organisasi atau perusahaan (isu, krisis, kebijakan perusahaan) yang bersifat positif atau tidak bertentangan dengan persepsi organisasi. Persepsi dalam hal ini dianggap sebagai "the picture of head" akan menentukan bagaimana publik berperilaku.

Sehingga berdasarkan definisi tersebut, dapat dikatakan bahwa public relations merupakan ahli strategi framing perusahaan yang berperan untuk membuat pesan dengan menyeleksi atau menonjolkan bagian-bagian tertentu ari sebuah realitas untuk disampaikan kepada publik. Pesanpesan tersebut tentunya dapat berbagai macam, berupa pesan non-verbal maupun pesan verbal seperti press release.

Menurut Kriyantono (2008:146) press release adalah sebuah berita atau informasi yang disusun oleh sebuah organisasi yang menggambarkan kegiatannya (a piece of news written by the organization whose activities it describes). Pada umumnya, press release memiliki fungsi sebagai wahana informasi tentang kegiatan public relations yang dikirim 
ke media, dengan maksud agar informasi yang ada dalam press release dimuat dalam bentuk berita oleh media. Namun, seiring berjalannya waktu press release tidak hanya menjadi sarana publisitas semata, tetapi dapat menjadi sarana pembingkaian perusahaan. Alhasil, press release dapat dikatakan sebagai pseudo-news story atau berita yang sengaja diciptakan terkait peristiwa, figur, jasa, ataupun produk yang dapat mendongkrak reputasi dan citra perusahaan.

Berkaitan dengan hal tersebut, akhirnya menjelaskan bahwa secara implisit menjelaskan bahwa framing atau pembingkaian tidaklah terlepas dari aktivitas seorang public relations. Dimana hal ini kian memperkuat bahwa kendatinya memang frame tidak hanya berada pada ranah media saja. Namun, terdapat juga pada ranah korporasi atau perusahaan. Druckman (dalam Kriyantono, 2014:316) mendiskrispikan bahwa terdapat dua tipe frame, yakni: frame media massa, dan frame publik.

$$
\text { Namun, Kriyantono }
$$

(2014:316) menambahkan satu jenis frame yakni, frame organisasi. Frame organisasi merupakan frame yang dibuat oleh suatu organisasi (public relations) untuk mendefinisikan suatu peristiwa atau isu yang bertujuan untuk mempengaruhi opini publik sehingga terciptanya citra atau image organisasi yang positif.

Terlepas dari pada itu, dalam perspektif framing public relations Hallahan (dalam Kriyantono, 2014:318) menyampaikan tujuh model framing yang dapat digunakan dalam praktik public relations, antara lain: framing situasi, framing atribusi, framing pilihan resiko, framing tindakan, framing isu, framing tanggung jawab, framing berita. Berikut peneliti sertakan tabel yang menjabarkan ketujuh model framing dalam public relations tersebut dan bagaimana aplikasi atau penerapannya dalam praktik public relations:

Tabel 1.

Tujuh Model Framing dalam Proses Public Relations

\begin{tabular}{|c|l|l|}
\hline $\begin{array}{c}\text { Apa yang } \\
\text { di-frame? }\end{array}$ & \multicolumn{1}{|c|}{ Deskripsi } & Aplikasi dalam Praktik Public Relations \\
\hline Situasi & $\begin{array}{l}\text { Relasi antara individu dalam situasi } \\
\text { sehari-hari, termasuk proses } \\
\text { interaksi, negosiasi, maupun } \\
\text { diskusi. }\end{array}$ & $\begin{array}{l}\text { Public relations harus dapat mem-frame } \\
\text { event agar dapat memenuhi ekspetasi publik } \\
\text { dan dapat mendorong motivasi publik. }\end{array}$ \\
\hline Atribusi & $\begin{array}{l}\text { Memberi penekanan pada } \\
\text { karateristik tertentu dari objek atau } \\
\text { peristiwa dan mengabaikan } \\
\text { karateristik lainnya dari suatu objek } \\
\text { atau peristiwa. }\end{array}$ & $\begin{array}{l}\text { Public relations member atribusi (label) } \\
\text { pada aspek-aspek tertentu dari organisasi } \\
\text { atau isu seperti produk, pelayanan, kandidat, } \\
\text { membuat positioning produk. }\end{array}$ \\
\hline
\end{tabular}




\begin{tabular}{|c|c|c|}
\hline $\begin{array}{l}\text { Pilihan } \\
\text { Resiko }\end{array}$ & $\begin{array}{l}\text { Meletakkan keputusan alternatif } \\
\text { dalam istilah negatif (kerugian) dan } \\
\text { positif (keuntungan) dapat } \\
\text { memengaruhi pilihan di situasi di } \\
\text { mana terjadi ketidakpastian. Teori } \\
\text { prospect menjelaskan bahwa } \\
\text { individu lebih suka menanggung } \\
\text { resiko untuk menghindari efek } \\
\text { negatif daripada efek positif. }\end{array}$ & $\begin{array}{l}\text { Sangat berguna untuk Public relations yang } \\
\text { berupaya memengaruhi publik untuk } \\
\text { mengambil keputusan di mana ada resiko- } \\
\text { resiko yang terjadi. Praktisi public relations } \\
\text { mem-frame pesannya dengan memberikan } \\
\text { penekanan pada "perlunya keinginan } \\
\text { menanggung resiko untuk menghindari } \\
\text { kerugian menanggung resiko yang sama } \\
\text { untuk mendapatkan keuntungan." }\end{array}$ \\
\hline Tindakan & $\begin{array}{l}\text { Pada konteks persuasif, } \\
\text { kecenderungan individu untuk } \\
\text { bertindak meraih tujuan yang } \\
\text { diinginkan sangat dipengaruhi oleh } \\
\text { apakah pesan tentang tindakan } \\
\text { tertentu dinyakan dengan } \\
\text { menggunakan istilah negatif atau } \\
\text { positif. }\end{array}$ & $\begin{array}{l}\text { Digunakan untuk memilih cara terbaik } \\
\text { dalam menyusun pesan tentang "perilaku } \\
\text { yang tepat dilakukan oleh publik" untuk } \\
\text { meraih tujuan yang diinginkan. }\end{array}$ \\
\hline Isu & $\begin{array}{l}\text { Sebagai pendekatan untuk } \\
\text { menganalisa interpretasi atas } \\
\text { realitas sosial. Problem sosial dan } \\
\text { perdebatan (pro-kontra) didalamnya } \\
\text { dapat dijelaskan dalam berbagai } \\
\text { pilihan istilah (interpretasi) oleh } \\
\text { pihak-pihak yang berbeda yang } \\
\text { saling bersaing agar intepretasi } \\
\text { mereka terhadap problem atau } \\
\text { situasi sosial itu dianggap sebagai } \\
\text { kebenaran. }\end{array}$ & $\begin{array}{l}\text { Isu akan memunculkan pro-kontra. Isu } \\
\text { berkemampuan mengorganisasikan } \\
\text { individu ke dalam kelompok publik tertentu, } \\
\text { dimana setiap individu akan memberikan } \\
\text { interpretasinya terhadap suatu isu dan } \\
\text { berkeinginan agar interpretasinya diikuti } \\
\text { oleh orang lain. Public relations mem- } \\
\text { framing suatu isu sebagai suatu agenda } \\
\text { publik dan sebagai bagian penting } \\
\text { manajemen isu, yaitu untuk mengontrol } \\
\text { perkembangan isu. Framing isu berperan } \\
\text { untuk mem-frame pesan untuk } \\
\text { memengaruhi interpretasi publik atas suatu } \\
\text { isu agar sama dengan interpretasi } \\
\text { organisasi. }\end{array}$ \\
\hline $\begin{array}{l}\text { Tanggung } \\
\text { Jawab }\end{array}$ & $\begin{array}{l}\text { Setiap isu akan memunculkan } \\
\text { pertanyaan siapa penyebab dan } \\
\text { siapa yang akan bertanggung jawab. } \\
\text { Individu akan cenderung } \\
\text { memberikan atribut tentang } \\
\text { penyebab suatu peristiwa (biasanya } \\
\text { pada suatu krisis), baik faktor } \\
\text { internal atau eksternal, berdasarkan } \\
\text { pada level stabilitas dan kontrol. }\end{array}$ & $\begin{array}{l}\text { Public relations mem-frame pesannya } \\
\text { untuk menerima atau menolak tanggung } \\
\text { jawab atas terjadinya suatu peristiwa. } \\
\text { Biasanya frame ini bagian dari crisis } \\
\text { management dan menjaga reputasi korporat. }\end{array}$ \\
\hline Berita & $\begin{array}{l}\text { Deskripsi tentang bagaimana suatu } \\
\text { peristiwa/isu di-frame oleh media } \\
\text { dalam bentuk berita. Peristiwa itu } \\
\text { di-frame oleh media dengan } \\
\text { menggunakan istilah yang mudah } \\
\text { dimengerti dan membuat } \\
\text { interpretasi media bergema luas dan } \\
\text { bisa mempengaruhi opini publik. }\end{array}$ & $\begin{array}{l}\text { Public relations mem-frame pesan- } \\
\text { pesannya yang bisa menjaga citra organisasi } \\
\text { saat mengirim informasi ke media massa. } \\
\text { Frame Public relations ini juga harus } \\
\text { mengandung news-values, karena media } \\
\text { akan mem-frame tulisan Public relations } \\
\text { sesuai dengan news-values yang dianggap } \\
\text { media menarik perhatian khalayaknya. }\end{array}$ \\
\hline
\end{tabular}

Sumber: Kriyantono, 2014;318-320 
Sekalipun framing jarang digunakan dalam praktik public relations, namun begitu tetaplah penting. Dalam mengembangkan program seorang public relations perlu menggunakan berbagai strategi framing yang menentukan bagaimana suatu situasi, atribusi, pilihan, tindakan, serta tanggung jawab harus disampaikan kepada publik dengan tujuan memberikan hasil yang sesuai harapan organisasi (Prastya, 2016:195).

Sebagai contoh, pada kasus krisis yang menimpa maskapai penerbangan AirAsia Indonesia atas imbas dari kecelakaan jatuh dan hilangnya pesawat QZ8501, pihak maskapai penerbangan AirAsia Indonesia mengeluarkan sejumlah press release guna untuk memberikan informasi terkait dan terikini atas perkembangan dari kasus krisis tersebut. Namun, selain menjadi sarana publisitas semata, press release yang dikeluarkan oleh pihak maskapai penerbangan AirAsia Indonesia juga dijadikan sebagai sarana pembingkaian perusahaan. Terlihat, dalam berbagai siaran press release-nya, pihak maskapai penerbangan AirAsia Indonesia mencondongkan berbagai pesan yang menunjukan bagaimana tanggung jawab perusahaan yang berujung pada bagaimana atribusi maskapai tersebut dibentuk di benak para publik, khususnya pada publik eksternal maskapai. Seperti halnya, menyediakan berbagai bantuan yang ditujukan kepada keluarga korban, menemani pemakaman penumpang, menyediakan berbagai fasilitas yang menunjang upaya pencarian serta evakuasi, dsb.

Berdasarkan hal tersebut, dapat terlihat bagaimana aktivitas framing yang dilakukan oleh praktisi public relations bukanlah suatu yang "taken-for-granted", namun public relations merupakan pihak yang secara aktif melakukan konstruksi atas realitas yang terjadi. Adapun proses konstruksi atau framing didasari oleh tiga hal penting, meliputi: inklusi (inclusion), kedua eksklusi (exclusion), dan ketiga penekanan (emphasis). Inklusi (inclusion) merupakan proses memilih peristiwa, kata, gambar, atau foto-foto untuk disampaikan kepada orang lain. Eklusi (exclusion) adalah proses untuk tidak menyampaikan (mengabaikan) suatu peristiwa, kata, gambar, atau foto. Sedangkan, penekanan (emphasis) dilakukan untuk mendapatkan efek pesan yang tinggi, seperti suatu pesan yang diulang-ulang atau foto yang dicetak dalam ukuran yang besar, pemberian garis bawah pada suatu kata. Hingga akhirnya menjelaskan bahwa framing menentukan bagaimana realitas itu hadir dihadapan pembaca. Apa yang kita tahu tentang realitas sosial pada dasarnya tergantung pada bagaimana kita melakukan frame atas peristiwa itu, dimana kita akan memberikan pemahaman dan pemaknaan tertentu atas suatu peristiwa (Eriyanto, 2002:82). Sehingga, dapat dikatakan bahwa suatu frame akan membatasi atau 
mendefinisikan makna pesan pada diri seseorang.

Pada realitasnya, analisa framing dapat dijelaskan melalui berbagai metode, seperti halnya analisa framing menurut Murray Edelman, analisa framing menurut Gamson dan Modigliani, analisa framing menurut Zhongdan Pan dan Gerald M. Kosicki, serta analisa framing menurut Robert Entman. Namun, dalam penelitian ini peneliti lebih tertarik untuk menggunakan model analisa framing menurut Robert Entman untuk mengetahui bagaimana bingkai krisis QZ8501 pada berbagai siaran press release AirAsia Indonesia yang dimuat dalam situs website www.qz8501.airasia.com. Dimana Dalam konsepsi framing menurut Robert Entman (Eriyanto, 2002:188), framing pada dasarnya merujuk pada pemberian definisi, penjelasan, evaluasi, dan rekomendasi dalam suatu wacana untuk menekankan kerangka berpikir terntentu terhadap peristiwa yang diwacanakan. Konsepsi framing menurut Robert Entman tersebut menggambarkan secara luas bagaimana suatu fenomena, peristiwa, atau suatu realitas dimaknai dan ditandakan oleh media ataupun wartawan.

\section{Tabel 2.}

Kerangka Analisa Framing Entman

\begin{tabular}{|l|l|}
\hline Define Problems & Bagaimana suatu \\
(Pendefinisian & peristiwa atau isu \\
masalah) & dilihat? Sebagai apa? \\
\hline
\end{tabular}

\begin{tabular}{|c|c|}
\hline & $\begin{array}{l}\text { Atau sebagai masalah } \\
\text { apa? }\end{array}$ \\
\hline $\begin{array}{l}\text { Diagnose Causes } \\
\text { (Memperkirakan } \\
\text { masalah atau sum- } \\
\text { ber masalah) }\end{array}$ & $\begin{array}{l}\text { Peristiwa itu dilihat } \\
\text { disebabkan oleh apa? } \\
\text { Apa yang dianggap } \\
\text { sebagai penyebab dari } \\
\text { suatu masalah? Siapa } \\
\text { (aktor) yang dianggap } \\
\text { sebagai penyebab ma- } \\
\text { salah? }\end{array}$ \\
\hline $\begin{array}{l}\text { Make Moral } \\
\text { Judgement } \\
\text { (Membuat }\end{array}$ & $\begin{array}{l}\text { Nilai moral apa yang } \\
\text { disajikan untuk men- } \\
\text { jelaskan masalah? Nilai } \\
\text { moral apayang dipakai } \\
\text { untuk melegitimasi atau } \\
\text { mendelegitimasi suatu } \\
\text { tindakan? }\end{array}$ \\
\hline $\begin{array}{l}\text { Treatment } \\
\text { Recommendation } \\
\text { (Menekankan } \\
\text { penyelesaian) }\end{array}$ & $\begin{array}{l}\text { Penyelesaian apa yang } \\
\text { ditawekan untuk meng- } \\
\text { atasi masalah atau isu? } \\
\text { Jalan apa yang dita- } \\
\text { warkan dan ditempuh } \\
\text { untuk menangani atau } \\
\text { mengatasi masalah? }\end{array}$ \\
\hline
\end{tabular}

Sumber: Eriyanto, 2002:188

Berikut penjelasan lebih lanjut mengenai perangkat framing yang digunakan oleh Robert Entman:

\section{a. Define Problems}

Define problems atau pengidentifikasian masalah (Eriyanto, 2002:189) adalah elemen pertama kali yang dapat kita lihat mengenai 
framing. Elemen ini merupakan master frame atau bingkai yang paling utama. Define problems menjelaskan bagaimana peristiwa dipahami oleh wartawan.

\section{b. Diagnose Causes}

Diagnose causes atau memperkirakan penyebab masalah (Eriyanto, 2002:190) merupakan elemen framing untuk membingkai siapa yang dianggap sebagai aktor dari suatu peristiwa. Penyebab disini bisa berarti apa (what), tetapi juga bisa berarti siapa (who). Bagaimana peristiwa diapahami, tentu saja menentukan apa dan siapa yang dianggap sebagai sumber penyebab masalah.

\section{c. Make Moral Judgment}

Make moral judgment atau membuat pilihan moral (Eriyanto, 2002: 191) adalah elemen framing yang dipakai untuk membenarkan atau memberi argumentasi pada pendefinisian masalah yang sudah dibuat. Ketika masalah sudah didefinisikan, penyebab sudah ditentukan, maka diperlukan argumentasi yang kuat untuk mendukung gagasan tersebut.

\section{d. Treatment Recommendation}

Treatment recommendation atau menekankan penyelesaian masalah (Eriyanto, 2002:191) merupakan elemen yang dipakai untuk menilai apa yang dikehendaki oleh wartawan, dan jalan apa yang dipilih untuk menyelesaikan masalah. Penyelesaian sangat bergantung pada bagaimana peristiwa itu dilhat dan siapa yang dipandang sebagai penyebab masalah.

Robert Entman menjelaskan bahwa peritiwa atau realitas yang sama dapat dimaknai dan dikonstruksi secara berbeda oleh media (Eriyanto, 2002:195). Pemaknaan dan pemahaman yang berbeda itu bisa ditandai dari pemakaian label, kata, kalimat, grafik, dan penekanan tertentu dalam narasi berita. Sehingga, melalui analisa model framing menurut Robert Entman ini peneliti dapat melihat bagaimana krisis dilihat atau dipandang, siapa penyebab krisis tersebut, penyelesaian apa yang ditawarkan dalam krisis tersebut, dan nilai moral apakah yang disajikan untuk menjelaskan masalah atau krisis dalam penulisan press release, khususnya terkait krisis QZ8501 yang menimpa maskapai penerbangan AirAsia Indonesia.

\section{METODE PENELITIAN}

Pada penelitian ini, pendekatan yang digunakan adalah pendekatan kualitatif dengan jenis penelitian deskriptif. Pendekatan kualitatif merupakan penelitian yang berupaya untuk menjelaskan fenomena dengan sedalam-dalamnya melalui pengumpulan data sedalam-dalamnya (Kriyantono, 2006:56). Sedangkan, penelitian jenis deskriptif merupakan penelitian yang bertujuan untuk menggambarkan realitas yang terjadi tanpa 
menjelaskan hubungan antarvariabel

(Kriyantono, 2006:69).

Teknik pengumpulan data yang digunakan dalam penelitian ini adalah metode dokumentasi. Metode dokumentasi merupakan instrumen pengumpulan data yang sering digunakan dengan tujuan untuk mendapatkan informasi yang mendukung analisis dan intepretasi data (Kriyantono, 2006:120). Dokumen yang digunakan dalam penelitian ini merupakan dokumen bersifat publik, yakni: press release yang disiarkan pada situs resmi website AirAsia Indonesia www.qz8501.com.

Metode yang digunakan dalam penelitian ini adalah metode dengan menggunakan model analisis framing menurut Robert Entman (Eriyanto, 2002:188). Dalam pendekatan model analisis framing Entman tersebut, perangkat framing dibagi dalam empat struktur besar, antara lain: define problems, diagnose causes, make moral judgement, serta treatment recommendation yang pada dasarnya merujuk pada pemberian definisi, penjelasan, evaluasi, dan rekomendasi dalam suatu wacana untuk menekankan kerangka berpikir tertentu terhadap peristiwa yang diwacanakan. Sehingga apabila ditarik penghubung antara bingkai krisis QZ8501 melalui konsepsi analisa framing menurut Robert Entman tersebut, peneliti dapat melihat bagaimana krisis QZ8501 dilihat, siapa aktor atau penyebab krisis tersebut, penyelesaian apa yang ditawarkan dalam krisis tersebut, dan nilai moral apakah yang disajikan untuk menjelaskan masalah atau krisis tersebut.

\section{HASIL DAN PEMBAHASAN}

Pada sub-bab ini peneliti akan menjelaskan secara mendalam mengenai bingkai krisis QZ8501 dalam press release milik maskapai penerbangan AirAsia Indonesia yang dimuat dalam situs resmi website www.qz8501.airasia.com. Oleh karena itu, guna memermudah analisis pembingkaian (framing) yang dilakukan, peneliti membagi berbagai press release tersebut ke dalam tiga kategori besar, yakni kategori tahap krisis yang tediri dari: precrisis, acute-crisis, dan pasca-crisis.

Selanjutnya, untuk pembahasan yang framing yang lebih rinci, peneliti akan menggunakan beberapa poin penting dalam analisis framing menurut Robert Entman yang terdiri dari: define problems (pendefinisian masalah), diagnose causes (memperkirakan masalah atau sumber masalah), make moral judgment (membuat keputusan moral), dan treatment recommendation (menekankan penyelesaian).

Pertama pada tahap pre-crisis, peneliti mengelompokkan dan meneliti sejumlah press release, yang terhitung sejak tanggal 28 Desember 2014 hingga 1 Januari 2015. Adapun dalam tahap pre-crisis tersebut, peneliti menemukan hasil frame besar, yakni: kecelakaan pesawat QZ8501 merupakan 
natural crisis yang menimpa maskapai penerbangan AirAsia Indonesia. Lebih lanjut, frame besar tersebut akan peneliti jabarkan sebagai berikut:

Tabel 3.

\section{Komponen Framing Tahap Pre-Crisis}

\begin{tabular}{|c|c|}
\hline $\begin{array}{c}\text { Define Problems } \\
\text { (Pendefinisian } \\
\text { masalah) }\end{array}$ & $\begin{array}{l}\text { Terjadi kecelakaan } \\
\text { parah yang menimpa } \\
\text { pesawat penerbangan } \\
\text { QZ8501. }\end{array}$ \\
\hline $\begin{array}{c}\text { Diagnose Causes } \\
\text { (Memperkirakan } \\
\text { masalah atau } \\
\text { sumber masalah) }\end{array}$ & $\begin{array}{l}\text { Kondisi cuaca sebagai } \\
\text { faktor utama penyebab } \\
\text { terjadinya insiden } \\
\text { kecelakaan yang } \\
\text { menimpa pesawat } \\
\text { penerbangan QZ8501. }\end{array}$ \\
\hline $\begin{array}{c}\text { Make Moral } \\
\text { Judgment } \\
\text { (Membuat } \\
\text { keputusan moral) }\end{array}$ & $\begin{array}{l}\text { Kecelakaan pesawat } \\
\text { QZ8501 adalah insiden } \\
\text { tanpa adanya unsur } \\
\text { kesengajaan dari pihak } \\
\text { maskapai. }\end{array}$ \\
\hline $\begin{array}{c}\text { Treatment } \\
\text { Recommendation } \\
\text { (Menekankan } \\
\text { penyelesaian) }\end{array}$ & $\begin{array}{c}\text { Prioritas dan } \\
\text { penanganan lebih lanjut } \\
\text { terkait kecelakaan } \\
\text { pesawat QZ8501. }\end{array}$ \\
\hline
\end{tabular}

Sumber: Hasil olahan peneliti

Pada tahap pre-crisis ini, peneliti melihat bahwa pihak maskapai penerbangan AirAsia Indonesia memunculkan frame define problems, yakni: terjadi kecelakaan parah yang menimpa pesawat penerbangan QZ8501. Adapun hasil frame define problems tersebut peneliti temukan pertama kali pada penulisan press release pada tanggal 30 Desember
2014. Dalam press release tersebut, pihak maskapai penerbangan AirAsia Indonesia mengkonfirmasi kebenaran akan ditemukannya "serpihan" pesawat penerbanganQZ8501 milik maskapai penerbangan AirAsia Indonesia yang dikabarkan hilang kontak dengan ATC pada hari Minggu, 28 Desember 2014 lalu.

"AirAsia Indonesia dengan sangat menyesal menginformasikan bahwa Badan SAR Nasional (BASARNAS) hari ini mengkonfirmasi bahwa serpihan pesawat yang ditemukan siang tadi adalah bagian dari pesawat QZ8501 yang hilang kontak dengan air traffic control (ATC) pada 28 Desember 2014." (Paragraf 1 Surabaya, 30 Desember 2014)

"Adapun serpihan pesawat tersebut ditemukan di kawasan Selat Karimata, sekitar 110 mil laut barat daya dari Pangkalan Bun, Kalimantan." (Paragraf 2 - Surabaya, 30 Desember 2014)

Menurut International Investigation Standard Annex 13-Aircraft Accident and Incident Investigation, tenth Edition July2010, incomporationg Amendment 14 and supplement, Undang-Undang nomor 1 tahun 2009 tentang Penerbangan, dan Peraturan Pemerintah Republik Indonesia nomor 62, tahun 2013 tentang Investigasi Kecelakaan Transportasi, pasal 9 (Poerwanto dan Mauidzoh, 2016:12) menyatakan bahwa terdapat 4 klasifikasi kecelakaan penerbangan, antara lain: a.) pesawat udara yang jatuh pada saat tinggal landas, lepas landas, atau selama penerbangan, b.) tabrakan antar pesawat udara, atau pesawat udara dengan fasilitas yang terdapat di bandar 
udara, c.) pesawat penerbangan yang hilang atau tidak dapat ditemukan, dan d.) pesawat udara yang mengalami kecelakaan serius (serious accident).

Berdasarkan klasifikasi kecelakaan penerbangan tersebut, kecelakaan pesawat yang dialami oleh pesawat QZ8501 dapat dikategorikan kedalam klasifikasi kecelakaan serius. Hal ini diperkuat karena dalam pernyataan tersebut, pihak maskapai mengkonfirmasi bahwa tertemukannya "serpihan" akan pesawat penerbangan QZ8501. Pada dasarnya, kata serpihan memiliki definisi sebagai bagian-bagian kecil, bongkahan, ataupun kepingan dari sebuah benda (kbbi.web.id, diakses 20 Januari 2018). Merujuk pada definisi tersebut, tentunya melalui penulisan press release diatas pihak maskapai penerbangan AirAsia Indonesia memberikan gambaran kepada publik bahwa pesawat QZ8501 mengalami tabrakan kencang, atau kecelakaan yang parahsedemikian rupa sehingga meninggalkan berkas sisa serpihan.

Tidak hanya itu, penguatan akan bingkai define problems yang ditemukan diperkuat melalui pernyataan Sunu Widyatmoko selaku Presiden Direktur AirAsia Indonesia dan Tony Fernandes selaku Grup CEO AirAsia yang dimuat dalam press release 30 Desember 2014. Adapun dalam press release tersebut baik Sunu dan Tony menyampaikan perasaan dukanya mendapati kabar bahwa ditemukan serpihan pesawat QZ8501 yang ditemukan 110 mil laut barat daya dari Pangkalan Bun.

Presiden Direktur AirAsia Indonesia, Sunu Widyatmoko mengatakan, "Kami sungguh terpukul atas kejadian ini." (Paragraf 5 - Surabaya, 28 Desember 2014 pukul 22:57 WIB)

Sementara itu, Group Chief Executive Officer AirAsia, Tony Fernandes menambahkan, "Saya sungguh sedih atas kejadian ini. Ini adalah tragedi bagi kami semua di AirAsia." (Paragraf 6 Surabaya, 30 Desember 2014)

Berdasarkan penulisan diatas, dapat dilihat terdapat juru bicara yang nampak pada dua kutipan press release tersebut. Dimana menurut Kriyantono (2014:552) juru bicara diperlukan guna untuk memperkuat penjelasan organisasi. Dalam kasus ini, juru bicara digambarkan sebagai pihak yang benar-benar dapat dikatakan mewakili suara perusahaan, memiliki andil yang cukup besar dalam perusahaan tersebut serta memiliki kredibilitas serta news value yang tinggi yang sesuai dengan kebutuhan media massa. Merujuk pada penjelasan tersebut, dapat dilihat bahwa Sunu dan Tony merupakan sosok yang merepresentasikan perusahaan. Artinya dalam hal ini apa yang dilakukan dan dikatakan oleh Sunu maupun Tony menggambarkan bagaimana tindakan maupun kondisi maskapai penerbangan AirAsia Indonesia. Sehingga melalui penggalan kutipan pernyataan Sunu dan Tony diatas, dapat dilihat bahwa maskapai penerbangan AirAsia Indonesia ingin menggambarkan 
bagaimana terpuruknya kondisi maskapai di saat itu. Terlebih lagi, dalam kutipan Tony Fernandes beliau menjelaskan bahwa kasus kecelakaan pesawat QZ8501 merupakan tragedi bagi kami semua. Dimana dalam pandangan peneliti kata "tragedi" disini menjelaskan sebetapa buruknya kecelakaan yang menimpa pesawat QZ8501 hingga akhirnya menyebabkan maskapai mengalami kesedihan yang sangat begitu mendalam.

Pada bagian diagnose causes, peneliti menemukan diagnose causes, yakni: kondisi cuaca sebagai faktor utama penyebab terjadinya insiden kecelakaan yang menimpa pesawat penerbangan QZ8501. Adapun hasil frame diagnose causes tersebut peneliti temukan pada penulisan press release tanggal 28 Desember 2014. Dimana press release tersebut, maskapai penerbangan AirAsia Indonesia menuliskan informasi terkait kabar hilang kontaknya pesawat QZ8501 dengan dengan ATC pada pukul 07:24 WIB.

"AirAsia Indonesia dengan menyesal menginformasi bahwa pesawat QZ8501 dari Surabaya menuju Singapura hilang kontak dengan Air Traffic Control pada pukul 07:24 waktu Surabaya pagi ini." (Paragraf 1 - Jakarta, 28 Desember 2014 pukul 14:30 WIB)

Apabila ditelaah dan ditelusuri lebih dalam, sebenarnya penyebab akan hilang kontaknya suatu pesawat dapat disebabkan oleh berbagai faktor (baik faktor internal maupun faktor eksternal pesawat. Menurut Hari Muhammad selaku pengamat penerbangan yang berasal dari Institut
Teknologi Bandung (ITB), beliau menjelaskan bahwa hilang kontaknya suatu pesawat dapat disebabkan oleh rusaknya peralatan komunikasi atau sistem kelistrikan pesawat akibat mesin pesawat mati. Selain itu, menurut beliau rusaknya alat komunikasi dan sistem listrik pesawat hingga mesin pesawat mati dapat disebabkan oleh faktor teknis dan faktor cuaca (Siswadi, 2014 dalam bisnis.tempo.co, diakses pada 20 Januari 2018).

Sehingga apabila melihat pernyataan Hadi Muhammad tersebut, dapat ditarik kesimpulan bahwa sebenarnya terdapat “peluang" yang menjelaskan terkait adanya kerusakan dari dalam pesawat QZ8501 yang akhirnya berimbas pada hilang kontaknya pesawat dengan ATC saat itu. Namun, guna untuk mengaburkan pemikirian publik yang negatif tersebut, maka pihak maskapai penerbangan AirAsia Indonesia memilih untuk menyiapkan dan menuliskan berbagai fakta guna untuk mengurangi resiko muncul shock, kepanikan, serta kekhawatiran publik. Seperti halnya menuliskan terkait, kelayakan dari pesawat penerbangan QZ8501 yang dimuat dalam press release 28 Desember 2014.

"Adapun pesawat dalam kondisi layak terbang dan telah melakukan perawatan berjadwal terakhir pada 16 November 2014." (Paragraf 2 - Jakarta, 28 Desember 2014 pukul 14:30 WIB) 
Selain menuliskan terkait kelayakan penerbangan dari pesawat QZ8501. Pada tanggal yang sama, yakni pada hari Minggu, 28 Desember 2014, peneliti melihat bahwa pihak maskapai penerbangan AirAsia Indonesia kembali kembali memberikan penguat atas bingkai diagnose causes yang ditemukan dengan menuliskan pernyataan yang menjelaskan tentang riwayat kerja (jam terbang) dari pilot (captain) dan co-pilot (first officer) yang bertugas dalam penerbangan pesawat QZ8501 tersebut. Adapun pernyataan yang dimuat dalam press release tersebut adalah, sebagai berikut:

"Kapten yang memimpin penerbangan tersebut telah memiliki total jam terbang sebanyak 20.537 jam, dimana sebanyak 6.100 jam terbangnya dijalani bersama AirAsia Indonesia dengan pesawat Airbus A320. Sedangkan first officer atau co-pilot telah memiliki sebanyak 2.275 jam terbang." (Paragraf 8 - Surabaya, 28 Desember 2014 pukul 22:57 WIB)

Melalui dua penulisan penggalan kutipan tersebut, nampak dengan jelas bahwa pihak maskapai penerbangan AirAsia Indonesia menyangkal bahwa dirinya merupakan penyebab atas terjadinya kecelakaan yang menimpa pesawat penerbangan QZ8501. Dimana dalam pandangan peneliti, penyangkalan tersebut nampak jelas melalui penggunaan kata "layak" yang terdapat pada kutipan tersebut. Kata "layak" disini jelas memberikan pesan bahwa pesawat QZ8501 merupakan pesawat yang pantas untuk melakukan penerbangan. Dimana pesan pantas tersebut, tersirat melalui penulisan perawatan berjadwal yang akhirnya menjelaskan bahwa pihak maskapai telah bekerja secara totalitas sesuai dengan nilainilai perusahaan, yakni penuh integritas dengan bertindak hal yang benar setiap waktu, dengan cara melakukan pengecekan rutin serta kelayakan penerbangan suatu pesawat sebelum pesawat tersebut lepas landas.

Selain itu, aspek yang menjadi penguat dalam bingkai diagnose causes ditemukan melalui penulisan ribuan "jam terbang" yang dimiliki oleh pilot dan co-pilot pesawat penerbangan QZ8501. Dimana secara langsung, ribuan jam terbang tersebut jelas menampakkan bahwa kru yang bertugas dalam penerbangan tersebut merupakan kru yang benar-benar piawai atau handal dalam tugasnya, karena telah menekuni suatu profesi atau pekerjaan dalam kurun waktu yang sangat lama (ribuan jam).

Pada bagian make moral judgment, peneliti menemukan make moral judgment, yakni: kecelakaan pesawat QZ8501 adalah insiden tanpa adanya unsur kesengajaan dari pihak maskapai. Unsur ketidaksengajaan ini ditampilkan dan ditonjolkan oleh pihak maskapai melalui pertama kali diperkuat melalui pernyataan Sunu Widyatmoko yang dimuat dalam press release AirAsia Indonesia hari Minggu, 28 Desember 2014.

Presiden Direktur AirAsia Indonesia, Sunu Widyatmoko mengatakan “... 
Adapun kami tengah berkoordinasi dengan seluruh otoritas terkait guna menentukan penyebab akan kejadian ini."

(Paragraf 2 - Surabaya, 28 Desember 2014 pukul 22:57 WIB)

"Kami akan memberikan dukungan sepenuhnya sejalan dengan proses investigasi yang saat ini tengah berlangsung." (Paragraf 3 - Surabaya, 28 Desember 2014 pukul 22:57 WIB)

Melalui dua penggalan kutipan Sunu Widyatmoko tersebut, nampak jelas bagaimana dalam kasus kecelakaan ini pihak maskapai penerbangan AirAsia Indonesia menggambarkan pihaknya sebagai pihak yang "innocent" dan tidak ikut campur tangan dalam penyebab terjadinya kecelakaan pesawat QZ8501. Dimana ketidak tahuan dan tidak ikut campur tangannya maskapai tersebut nampak jelas melalui berbagai penulisan yang menuliskan bahwa pihak maskapai akan menentukan penyebab akan kejadian ini serta penulisan dukungan terkait proses investigasi yang tengah berlangsung. Adapun dalam pandangan peneliti, penulisan akan kata "proses investigasi" yang disebutkan oleh Sunu Widyatmoko tersebut menjadi kunci utama atas tertemukannya bingkai make moral judgment dalam tahap pre-crisis ini. Menurut Santana (dalam Harmonis, 2006:10) investigasi adalah penyelidikan secara mendalam guna untuk mengungkapkan kebenaran atas sebuah hipotesa (kesimpulan sementara). Sehingga apabila pernyataan bantuan Sunu Widyatmoko dikaitkan dengan penjelasan diatas, maka dapat ditarik suatu kesimpulan akan gambaran bahwa dalam kasus ini pihak maskapai penerbangan AirAsia Indonesia benar-benar tidak mengetahui (innocent) akan apa, atau siapa penyebab, maupun bagaimana kronologi terjadinya kecelakaan yang menimpa pesawat penerbangan QZ8501 hingga akhirnya membuat pihak maskapai membantu pelaksanaan serangkaian proses investigasi guna untuk menemukan kejelasan atas masalah tersebut.

Terakhir, pada bagian treatment recommendation, peneliti menemukan make moral judgment, yakni: prioritas dan penanganan lebih lanjut terkait kecelakaan pesawat QZ8501. Bingkai treatment recommendation ini peneliti dapat melalui penulisan pada press release tanggal 28, 30 Desember 2014, pihak maskapai menuliskan terkait pembentukan tim pendukung untuk membantu kebutuhan keluarga serta penyediaan ruang pusat informasi terpadu yang dapat digunakan oleh keluarga penumpang pesawat QZ8501.

“... Selain itu, kami telah membentuk tim pendukung untuk membantu dalam memenuhi kebutuhan para keluarga, maupun kerabat termasuk akomodasi dan transportasi. Pusat informasi terpadu juga telah kami siapkan di Surabaya untuk keluarga penumpang." (Paragraf 3 - Surabaya, 28 Desember 2014 pukul 22:57 WIB)

"AirAsia Indonesia akan mengundang seluruh anggota keluarga penumpang QZ8501 ke Surabaya, dimana kami akan memberikan tim konseling khusus kepada setiap keluarga guna mendukung dan memastikan segala 
kebutuhan mereka terpenuhi. Kami juga telah mengundang berbagai konselor psikologi dan spiritual termasuk para pemuka agama guna memberikan dukungan moril kepada seluruh keluarga penumpang." (Paragraf 7 Surabaya, 30 Desember 2014)

Melalui penulisan diatas, dalam hal ini jelas terlihat bagaimana pihak maskapai penerbangan AirAsia Indonesia menempatkan kebutuhan keluarga menjadi kewajiban utama yang diemban oleh pihak maskapai. Dimana melalui gambaran kewajiban tersebut, terlihat bagaimana maskapai penerbangan AirAsia Indonesia mengedepankan nilai "prioritas" sebagai salah satu penekanan penyelesaian yang ingin disampaikan dalam kasus ini. Terlebih lagi, bukti akan prioritas utama yang ingin ditampakkan oleh pihak maskapai penerbangan AirAsia Indonesia dengan menuliskan akan adanya upaya penanganan yang dilakukan terus menerus.

"AirAsia hari ini telah menerima konfirmasi dari Badan SAR Nasional (BASARNAS) bahwa upaya pencarian pesawat QZ8501 yang hilang kontak kemarin (28/12) akan terus dilakukan dan mendapat dukungan dari tim SAR Malaysia dan Singapura." (Paragraf 1 Surabaya, 29 Desember 2014)

"AirAsia Indonesia bersama ini hendak memberikan informasi terkini bahwa Badan SAR Nasional (BASARNAS) Repbulik Indonesia dan otoritas terkait terus berupaya untuk mencari dan mengevakuasi penumpang QZ8501 di wilayah Selat Karimata." (Paragraf 1 Surabaya, 31 Desember 2014)
Berdasarkan penulisan dua kutipan diatas, nampak terlihat jelas bahwa maskapai penerbangan AirAsia Indonesia menuliskan kata melakukan pengupayaan yang "terus menerus", pada dasarnya kata "terus" sendiri mengisyaratkan akan kegiatan yang berlanjut atau tiada henti. Sehingga apabila dikombinasikan dalam penulisan diatas, nampak terlihat penekanan penyelesaian yang ingin ditampakkan oleh maskapai penerbangan AirAsia Indonesia yakni penanganan kasus yang terus menerus berlanjut (penanganan tingkat lanjut) yang tidak akan berhenti hingga mendapatkan hasil yang sesuai dengan yang diinginkan.

Selanjutnya pada tahap acute-crisis, peneliti mengelompokkan dan meneliti sejumlah press release, yang terhitung sejak tanggal 2 hingga 30 Januari 2015. Adapun dalam tahap acute-crisis tersebut, peneliti menemukan hasil frame besar, yakni: lambatnya upaya penanganan kasus kecelakaan pesawat QZ8501. Lebih lanjut, frame besar tersebut akan peneliti jabarkan sebagai berikut:

\section{Tabel 4.}

\section{Komponen Framing Tahap Acute-Crisis}

\begin{tabular}{|c|c|}
\hline $\begin{array}{c}\text { Define Problems } \\
\text { (Pendefinisian }\end{array}$ & $\begin{array}{c}\text { Terkendalanya upaya } \\
\text { penanganan kasus } \\
\text { masalah) }\end{array}$ \\
$\begin{array}{c}\text { kecelakaan pesawat } \\
\text { QZiagnose Causes }\end{array}$ & Cuaca menjadi \\
(Memperkirakan & tantangan utama \\
\hline
\end{tabular}




\begin{tabular}{|c|c|}
\hline $\begin{array}{c}\text { masalah atau } \\
\text { sumber masalah) }\end{array}$ & $\begin{array}{l}\text { operasi pencarian dan } \\
\text { evakuasi penumpang. }\end{array}$ \\
\hline $\begin{array}{c}\text { Make Moral } \\
\text { Judgment } \\
\text { (Membuat } \\
\text { keputusan moral) }\end{array}$ & $\begin{array}{c}\text { Kebergantungan rekan } \\
\text { tim penyelamat } \\
\text { BASARNAS pada } \\
\text { kondisi cuaca. }\end{array}$ \\
\hline $\begin{array}{c}\text { Treatment } \\
\text { Recommendation } \\
\text { (Menekankan } \\
\text { penyelesaian) }\end{array}$ & $\begin{array}{l}\text { Publik diminta untuk } \\
\text { bersabar dalam } \\
\text { menunggu hasil } \\
\text { pencarian dan } \\
\text { evakuasi. }\end{array}$ \\
\hline
\end{tabular}

Sumber: Hasil olahan peneliti

Pada tahap acute-crisis ini, peneliti melihat bahwa pihak maskapai penerbangan AirAsia Indonesia memunculkan frame define problems, yakni: terkendalanya upaya penanganan kasus kecelakaan pesawat QZ8501. Adapun hasil frame define problems tersebut peneliti temukan pertama kali pada penulisan press release pada tanggal 17 dan 18 Januari 2015, maskapai penerbangan AirAsia Indonesia menuliskan bahwa terdapatnya kondisi cuaca buruk yang mengakibatkan upaya penanganan pada hari itu menjadi terhambat atau terkendala.

“... Namun, kapal dan tim penyelam SAR tetap siaga di area pencarian untuk melanjutkan observasi bawah laut di saat cuaca kembali bersahabat."

(Paragraf 2 - Surabaya, 17 Januari 2015)

“... Namun, BASARNAS memastikan bahwa misi pencarian dan evakuasi penumpang QZ8501 masih menjadi prioritas karena diduga masih banyak penumpang yang terjebak dalam serpihan badan pesawat sehingga operasi SAR akan dilanjutkan esok hari." (Paragraf 3 - Surabaya, 18 Januari 2015)

Menurut Kriyantono (2015:250) menjadi suatu hal yang penting dalam menghadapi sebuah krisis dimana sebuah organisasi harus menyampaikan segala informasi dan tidak menutup-nutupinya. Dimana kunci dalam menyampaikan informasi tersebut adalah jangan sampai informasi tersebut malah membuat reputasi organisasi atau perusahaan menjadi menurun.

Melihat penjelasan tersebut, tentunya pada kasus ini pihak maskapai penerbangan AirAsia Indonesia berusaha untuk mengaburkan fakta yang menjelaskan bahwa sebenarnya upaya penanganan pada itu gagal. Dimana peneliti melihat, pengaburan fakta tersebut digambarkan pihak maskapai dengan penggunaan kata "siaga" pada press release 17 Januari 2015 dan penggunaaan kata "prioritas utama" pada press release 18 Januari 2015. Melalui dua kata tersebut tentu pihak maskapai penerbangan AirAsia Indonesia ingin menjelaskan dan menggambarkan rekan tim penyelamat BASARNAS adalah rekan yang telah bekerja dengan sungguh-sungguh, dan memiliki komitmen tinggi untuk segera menyelesaikan upaya pencarian dan evakuasi. Sekalipun sebenarnya apabila ditelaah lebih mendalam, inti dalam dua kalimat tersebut adalah penjelasan akan upaya penanganan pada hari itu gagal dan akan dilanjutkan esok hari 
ketika cuaca membaik. Sehingga melalui penjelasan diatas dapat dilihat bahwa penggunaan kata dan kalimat dapat berpengaruh pada bagaimana citra perusahaan itu ditampakkan.

Selanjutnya, penguatan akan bingkai define problems juga ditampakkan secara lugas oleh maskapai penerbangan AirAsia melalui siaran press release pada tanggal 27 Januari 2015. Dimana dalam siaran press release tersebut, maskapai penerbangan AirAsia Indonesia menuliskan pernyataan Lakamana Muda Widodo selaku Panglima Komando Armada Republik Indonesia Kawasan Barat (Pangarmabar) yang menjelaskan terkait pengumuman ditariknya segala bentuk aset dan seluruh armada milik TNI dari area lokasi pencarian.

"Laksamana Muda Widodo
mengumumkan bahwa resuai
perintah dari Panglima TNI Jendral
Moeldoko, TNI telah menarik
armada dan pasukannya dari area
pencarian tersebut." (Paragraf $2-$
Surabaya, 27 Januari 2015)

Apabila mengingat dan membaca kembali pada press release 28 Desember 2014, pihak maskapai penerbangan AirAsia Indonesia menuliskan bahwa dalam penerbangannya pesawat QZ8501 membawa sebanyak 155 penumpang, dimana 137 penumpang adalah orang dewasa, 17 penumpang adalah anak-anak dan 1 bayi. Selain itu dalam penerbangan tersebut, pesawat penerbangan QZ8501 juga membawa beberapa kru (crew) yang bertugas, antara lain: 2 pilot, 4 awak kabin, dan 1 teknisi. Sehingga melihat penemuan fakta tersebut, nampak jelas bahwa hasil pencarian yang dilakukan oleh rekan tim penyelamat BASARNAS dan TNI hingga 27 Januari 2015 tidak mencapai $50 \%$ dari total seluruh penumpang yang hilang pada kecelakaan pesawat tersebut. Sehingga merujuk pada hal tersebut, semakin menjelaskan bahwa keputusan TNI untuk melepas kerja sama antara pihaknya dengan maskapai penerbangan AirAsia Indonesia terkait upaya penanganan dan evakuasi akan semakin memperkuat bingkai terkendalanya upaya penanganan kasus kecelakaan pesawat QZ8501.

Terlepas dari pada itu, melalui penulisan tersebut pihak maskapai penerbangan AirAsia Indonesia secara tidak langsung telah membentuk reputasi crisis history yang buruk, dimana dengan penulisan tersebut akan memunculkan persepsi publik yang menyatakan bahwa pihak maskapai tidak memperlakukan mereka dengan baik, sehingga tentunya akan memengaruhi bagaimana hubungan atau relasi antara pihak maskapai dengan para publik di kemudian hari.

Pada bagian diagnose causes, peneliti menemukan diagnose causes, yakni: cuaca menjadi tantangan utama operasi pencarian dan evakuasi penumpang. Adapun hasil frame diagnose causes tersebut peneliti temukan 
pada penulisan press release tanggal 5 dan 13

Januari 2015. Adapun dalam press release tersebut pihak maskapai penerbangan AirAsia Indonesia menyatakan dan menjelaskan secara lugas bahwa kondisi cuaca merupakan tantangan utama bagi rekan tim penyelamat Badan SAR Nasional (BASARNAS) ketika melakukan upaya operasi pencarian dan evakuasi penumpang pesawat penerbangan QZ8501.

"Cuaca masih menjadi tantang utama dari operasi pencarian dan evakuasi penumpang QZ8501 oleh Badan SAR Nasional (BASARNAS) dengan tinggi gelombang di kisaran 4-5 meter." (Paragraf 1 - Surabaya, 5 Januari 2015)

"Saat dialog berlangsung, Bambang Soelistyo meyakinkan keluarga bahwa operasi SAR masih berlangsung dengan prioritas mencari dan mengevakuasi penumpang walaupun cuaca dan arus bawah laut masih menjadi tantangan utama tim SAR." (Paragraf 4 Surabaya, 13 Januari 2015)

Pada dasarnya, realitas dapat terbentuk melalui penggunaan bahasa. Menurut Kriyantono (2015:286) bahasa adalah lambang yang terpenting dalam konstruksi sosial. Dalam hal ini bahasa dapat digunakan untuk diseminasi pesan dalam proses objektivasi dan internalisasi pengetahuan. Merujuk pada hal tersebut, tentunya dapat dilihat bahwa penulisan kata "utama" dalam dua penggalan kutipan diatas memiliki makna tertentu yang ingin disampaikan oleh pihak maskapai penerbangan AirAsia Indonesia. Dimana dalam pandangan peneliti, kata "utama" dalam penulisan press release diatas digunakan oleh maskapai penerbangan AirAsia Indonesia sebagai stimulus yang ingin disampaikan kepada publik. Adapun stimulus tersebut ditujukan agar publik dapat mempersepsi bahwa apabila terjadi kegagalan dalam upaya penanganan maka jawaban pertama atas kegagalan tersebut adalah karena faktor cuaca yang buruk dan bukan karena berbagai faktor lainnya.

Selanjutnya, penguatan akan bingkai diagnose causes juga ditampakkan oleh maskapai penerbangan AirAsia Indonesia pada siaran press release 8 Januari 2015. Adapun dalam press release tersebut, maskapai penerbangan AirAsia Indonesia menuliskan terkait keputusan dari rekan tim penyelamat SAR untuk tetap melanjutkan upaya proses pencarian dan evakuasi baik penumpang dan pesawat walaupun terhalang oleh kondisi cuaca yang tidak menentu, yakni kondisi cuaca dengan intesitas hujan ringan dan cukup berawan yang terjadi pada area sekitar pencarian pesawat.

"Tim SAR hari ini kembali melanjutkan proses pencarian walaupun dengan cuaca cukup terhalang dengan intesitas hujan ringan dan cukup berawan." (Paragraf 2 - Surabaya, 8 Januari 2015)

Dalam penggalan kutipan tersebut, nampak maskapai penerbangan AirAsia Indonesia menggunakan kata penghubung "walaupun" yang digunakan untuk menghubungkan satu kalimat dengan kalimat 
lainnya. Dimana apabila berdasarkan penjelasan diatas, kata penghubung walaupun dapat menjadi penguat yang menjelaskan tentang "pertentangan" usaha penyelamat rekan tim SAR dalam melakukan upaya proses pencarian dan evakuasi. Dimana "pertentangan" itu timbul karena rekan tim penyelamat SAR tetap melanjutkan upaya proses pencarian dan evakuasi di hari itu sekalipun cuaca yang buruk menjadi hambatan. Alhasil, berdasarkan makna "pertentangan" tersebut tentu disini dapat dilihat bahwa penulisan penggalan kutipan dalam press release diatas menjadi penguat akan bingkai diagnose causes yang ditemukan. Dimana dapat dilihat bahwa rekan tim penyelamat BASARNAS seakan-akan memiliki relasi yang buruk (permusuhan) dengan kondisi cuaca yang buruk yang dianggap sebagai tantangan utama rekan BASARNAS dalam melakukan proses upaya pencarian dan evakuasi penumpang pesawat QZ8501.

Pada bagian make moral judgment, peneliti menemukan make moral judgment, yakni: kecelakaan pesawat QZ8501 adalah kebergantungan rekan tim penyelamat BASARNAS pada kondisi cuaca. Kebergantungan tersebut ditonjolkan oleh maskapai penerbangan AirAsia Indonesia pada penulisan press release tanggal 20 Januari 2015. Dimana inti keseluruhan dari berbagai press release tersebut menjelaskan bahwa adanya pengaruh atau impact yang besar dari kondisi cuaca di area sekitar badan pesawat ditemukan terhadap hasil operasi pengangkatan badan pesawat QZ8501.

"Adapun tim SAR hari ini juga telah menerima sejumlah perangkat tambahan, antara lain berupa 12 lifting bags yang akan digunakan dalam mendukung upaya pengangkatan badan pesawat dari dasar laut. Namun, kepastian waktu operasi pengangkatan potongan badan pesawat sangat bergantung pada kondisi cuaca." (Paragraf 3 - Surabaya, 20 Januari 2015)

Melalui berbagai penggalan kutipan diatas, nampak secara jelas pernyataan maskapai penerbangan AirAsia Indonesia yang menjelaskan bahwa upaya pengangkatan badan pesawat penerbangan QZ8501 yang dilakukan oleh rekan tim penyelamat BASARNAS sangat bergantung pada kondisi cuaca. Dimana kata "kebergantungan" yang ditulis oleh maskapai penerbangan AirAsia Indonesia tersebut menjadi inti atau fokus penulisan atas segala permasalahan yang dihadapi oleh maskapai penerbangan AirAsia Indonesia saat melakukan operasi pengangkatan badan pesawat QZ8501 di berbagai hari tersebut.

Berdasarkan penggalan penulisan kutipan diatas, dapat terlihat bahwa sebenarnya pihak maskapai penerbangan AirAsia Indonesia memilih untuk menerapkan sub-strategi iktikad baik (good-intention). Iktikad baik tersebut dijelaskan oleh maskapai penerbangan AirAsia Indonesia melalui berbagai penulisan yang menjelaskan bahwa 
telah dilaksanakannya operasi pengangkatan badan pesawat QZ8501 sekalipun pada akhirnya ditutup oleh penulisan yang menjelaskan bahwa operasi pengangkatan tersebut terkendala (gagal) dikarenakan kondisi cuaca dan arus laut yang tidak mendukung. Sehingga dengan adanya penulisan iktikad baik tersebut, dapat dilihat bahwa maskapai penerbangan AirAsia Indonesia ingin menyampaikan kepada publik bahwa tim SAR telah bekerja keras di saat itu. Namun, melihat penulisan yang dilakukan berulang-ulang tersebut tentu mengaburkan akan nilai kerja keras yang ingin ditampakkan oleh maskapai penerbangan AirAsia Indonesia. Dimana nilai kerja keras tersebut berubah menjadi nilai "kebergantungan" rekan tim penyelamat BASARNAS karena operasi pengangkatan itu tidak hanya gagal pada sekali waktu, namun berkali-kali.

Terakhir, pada bagian treatment recommendation, peneliti menemukan make moral judgment, yakni: publik diminta untuk bersabar dalam menunggu hasil pencarian dan evakuasi. Adapun permohonan bersabar tersebut ditampakkan oleh maskapai penerbangan AirAsia Indonesia melalui penulisan press release pada tanggal 5 Januari 2015. Adapun dalam press release tersebut, pihak maskapai penerbangan AirAsia Indonesia menuliskan pernyataan Jenderal Moeldoko selaku Panglima TNI yang memin agar keluarga penumpang pesawat QZ8501 dapat terus bersabar menunggu hasil pencarian dan evakuasi yang tengah dilakukan oleh rekan tim penyelamat BASARNAS bersama TNI saat itu.

"Panglima TNI pun memohon kerja sama dari keluarga untuk tetap bersabar selama proses pencarian dan evakuasi berlangsung, karena seluruh tenaga baik dari Angkatan Darat, Angkatan Laut, dan Angkatan Udara telah bergabung untuk mendukung BASARNAS." (Paragraf 4 Surabaya, 5 Januari 2015)

Merujuk pada kualitas penulisan, pada dasarnya penulisan press release harus memerhatikan pentingnya akan kualitas penulisan seperti layaknya kualitas penulisan dalam berita. Berdasarkan penjelasan tersebut menandakan bahwa kualitas penulisan merupakan hal yang penting untuk diperhatikan oleh public relations. Dengan melihat penggalan kutipan diatas nampak disini pihak maskapai penerbangan AirAsia Indonesia mementingkan unsur relevan (relevance) dimana berita dibuat dengan mempertimbangkan kondisi saat berita itu disebarkan (Kriyantono, 2008:120). Adapun melihat penjelasan tersebut, tentunya pernyataan Jenderal Moeldoko yang dikutip oleh maskapai penerbangan AirAsia Indonesia pada press release tersebut memiliki makna eksplisit yang ingin disampaikan oleh pihak maskapai. Dimana dalam pandangan peneliti, permohonan bersabar yang disampaikan oleh Jenderal Moeldoko dijadikan sebagai jawaban utama yang ingin ditekankan oleh maskapai 
penerbangan AirAsia Indonesia atas segala masalah dalam upaya penanganan yang berimbas pada hasil akhir yakni lambatnya upaya penanganan kasus kecelakaan pesawat QZ8501 yang tengah dilakukan saat itu.

Terakhir pada tahap pasca-crisis, peneliti mengelompokkan dan meneliti sejumlah press release, yang terhitung sejak tanggal 2 hingga 30 Januari 2015. Adapun dalam tahap pasca-crisis tersebut, peneliti menemukan hasil frame besar, yakni: tidak berhasilnya upaya penanganan kasus kecelakaan pesawat QZ8501. Lebih lanjut, frame besar tersebut akan peneliti jabarkan sebagai berikut:

\section{KESIMPULAN}

Dari hasil penelitian dan pembahasan pada bab sebelumnya, sikap pelanggan listrik pascabayar Kabupaten Bangkalan mengenai sosialisasi program listrik pintar secara keseluruhan cenderung negatif. Berikut merupakan penjabaran sikap pelanggan listrik pascabayar mengenai sosialisasi program listrik pintar PT PLN (Persero) Ranting Bangkalan.

Pada sikap komponen kognitif secara keseluruhan, responden memiliki tingkat pengetahuan yang positif. Hal ini menunjukkan bahwa responden mengetahui sosialisasi program listrik pintar yang ditinjau dari segi elemen komunikasi dalam sosialisasi.
Pada komponen afektif secara kseluruhan, responden memiliki tingkat persetujuan yang positif. Hal ini menunjukkan bahwa responden menyetujui adanya sosialisasi program listrik pintar yang ditinjau dari segi elemen komunikasi dalam sosialisasi.

Pada komponen konatif secara keseluruhan, responden memiliki kecenderungan untuk berperilaku yang negatif. Hal ini menunjukkan bahwa responden tidak ingin beralih ke listrik pintar walaupun mudah melakukan pembayaran, lebih mudah dalam mengatur rekening listrik dan dapat mengatur sesuai dengan anggaran belanja.

Dari hasil analisis jawaban responden, penelitian ini telah menjawab pertanyaan dalam rumusan masalah penelitian. Jawaban dari rumusan masalah tersebut ialah pelanggan listrik pascabayar tidak mendukung adanya sosialisasi program listrik pintar. Sehingga secara keseluruhan memiliki arah sikap yang negatif. Pelanggan listrik pascabayar mengetahui, menyetujui namun tidak memiliki kecenderungan untuk beralih.

\section{SARAN}

Secara akademis, untuk penelitian selanjutnya agar dapat dilakukan penelitian studi kasus. Sehingga dapat memperdalam faktor-faktor yang mempengaruhi responden serta memperdalam teori sosialisasi dan komponen yang terdapat didalamnya. 
Secara praktis, bagi perusahaan yang akan melakukan sosialisasi mengenai program maupun kebijakan kepada masyarakat. Terlebih dahulu memperhatikan bagaimana karakteristik dari masyarakat. Terutama dari segi melalui apa sosialisasi tersebut dilakukan, sehingga dapat memilih saluran yang tepat dan efektif. Khususnya PT PLN (Persero) Ranting Bangkalan untuk mengemas strategi baru sesuai dengan target sosialisasi.

\section{Tabel 5.}

\section{Komponen Framing Tahap Pasca-Crisis}

\begin{tabular}{|c|c|}
\hline $\begin{array}{c}\text { Define Problems } \\
\text { (Pendefinisian } \\
\text { masalah) }\end{array}$ & $\begin{array}{c}\text { Terbengkalainya upaya } \\
\text { penanganan kasus } \\
\text { kecelakaan pesawat } \\
\text { QZ8501. }\end{array}$ \\
\hline $\begin{array}{c}\text { Diagnose Causes } \\
\text { (Memperkirakan } \\
\text { masalah atau } \\
\text { sumber masalah) }\end{array}$ & $\begin{array}{c}\text { Cuaca menjadi penentu } \\
\text { terlaksananya upaya } \\
\text { penanganan kasus } \\
\text { kecelakaan pesawat } \\
\text { QZ8501. }\end{array}$ \\
\hline $\begin{array}{c}\text { Make Moral } \\
\text { Judgment } \\
\text { (Membuat } \\
\text { keputusan moral) }\end{array}$ & - \\
\hline $\begin{array}{c}\text { Treatment } \\
\text { Recommendation } \\
\text { (Menekankan } \\
\text { penyelesaian) }\end{array}$ & $\begin{array}{c}\text { Penetupan operasi } \\
\text { pencarian dan evakuasi } \\
\text { (SAR) QZ8501. }\end{array}$ \\
\hline
\end{tabular}

Sumber: Hasil olahan peneliti

Pada tahap acute-crisis ini, peneliti melihat bahwa pihak maskapai penerbangan AirAsia Indonesia memunculkan frame define problems, yakni: terbengkalainya upaya penanganan kasus kecelakaan pesawat QZ8501. Adapun hasil frame define problems tersebut peneliti temukan pertama kali pada penulisan press release pada tanggal 20 Maret 2015. Adapun dalam press release tersebut, pihak maskapai penerbangan AirAsia Indonesia menuliskan dengan jelas terkait peresmian pemberhentian atau berakhirnya upaya proses pencarian dan evakuasi baik penumpang dan pesawat QZ8501 yang dilakukan oleh maskapai penerbangan AirAsia Indonesia bersama dengan rekan tim penyelamat BASARNAS.

"Tim Disaster Victim Identification
Kepolisian Republik Indonesia (DVI
POLRI) kemarin (19/03) berhasil
mengidentifikasi satu penumpang
yaitu Sharon Michelle Ang (wanita,
WNI) sehingga total jumlah
penumpang yang telah teridentifikasi
menjadi 97 penumpang." (Paragraf 3
- Surabaya, 20 Maret 2015)

Berdasarkan penulisan press release tersebut jelas tergambar bagaimana bingkai terbengkalainya kasus penanganan kecelakaan pesawat QZ8501. Adapun keterbengkalaian tersebut diperkuat karena hasil pencarian dan evakuasi hingga hari itu hanya mampu mengindentifikasi sebanyak 97 jenazah penumpang dari total 162 penumpang dan crew pesawat yang hilang pada penerbangan QZ8501 tersebut. Tentunya melihat berbagai penulisan press release diatas, dapat dilihat bahwa pihak maskapai penerbangan AirAsia Indonesia mengaburkan nilai komitmen yang 
diemban oleh maskapai. Dimana menurut Kriyantono (2015:243) komitmen adalah nilai terpenting yang perlu dijunjung tinggi oleh perusahaan disaat perusahaan tersebut mengalami sebuah krisis. Hal ini dikarenakan krisis bukan hanya masalah organisasi, tetapi masalah bersama karena dampak yang ditimbulkan oleh krisis sangatlah luas dan memengaruhi sistem sosial dan tidak hanya operasional organisasi. Namun, kenyataannya pihak maskapai tidak menyelesaikan krisis tersebut secara optimal melainkan membiarkan krisis tersebut terbengkalai.

Pada bagian diagnose causes, peneliti menemukan diagnose causes, yakni: cuaca menjadi penentu terlaksananya operasi pencarian dan evakuasi penumpang. Adapun hasil frame diagnose causes tersebut peneliti temukan pada penulisan press release tanggal 13 Februari 2015. Dimana dalam press release tersebut, pihak maskapai penerbangan AirAsia Indonesia menuliskan terkait terkendalanya operasi upaya pencarian dan evakuasi karena kondisi cuaca yang tidak memungkinkan (cukup ekstrim).

"Operasi SAR di area fokus pencarian di sekitar Selat Karimata dan Laut Jawa hari ini masih terkendala cuaca yang cukup ekstrim. Selain itu, seluruh kapal SAR saat ini juga masih merapat di Pelabuhan Kumai, Kalimantan Tengah guna pengisian bahan bakar dan kapal SAR akan kembali dikerahkan ke area fokus pencarian setelah cuaca membaik." (Paragraf 2 - Surabaya, 13 Februari 2015)
Berdasarkan berbagai penggalan kutipan penulisan diatas, nampak jelas bahwa dalam hal ini pihak maskapai penerbangan AirAsia Indonesia mengutarakan akan besarnya pengaruh cuaca dalam pelaksanaan upaya penanganan kasus kecelakaan pesawat QZ8501. Adapun dalam pandangan peneliti, peneliti melihat bahwa maskapai penerbangan AirAsia Indonesia menampilkan kondisi cuaca yang buruk dianggap sebagai batu sandungan yang menghambat upaya penanganan kasus kecelakaan pesawat QZ8501, sedangkan sebaliknya kondisi cuaca yang baik dianggap sebagai anugerah yang mendukung upaya penanganan kasus kecelakaan pesawat QZ8501 yang dilakukan oleh maskapai penerbangan AirAsia Indonesia bersama otoritas-otoritas terkait, seperti BASARNAS. Terlepas dari pada itu, penulisan kata "ekstrim" pada siaran press release diatas semakin memperkuat bentuk penghindaran tanggung jawab yang dilakukan oleh maskapai penerbangan AirAsia Indonesia. Dimana dalam kasus ini, kata “ekstrim" dijadikan maskapai penerbangan AirAsia Indonesia sebagai bukti kuat yang menyebabkan terhalangnya upaya pencarian dan evakuasi di saat itu.

Selanjutnya, pada tahap pasca-crisis ini pihak maskapai penerbangan AirAsia Indonesia menekankan penyelesaian, yakni penutupan operasi pencarian dan evakuasi (SAR) QZ8501. Dalam pandangan peneliti, penguatan akan bingkai treatment 
recommendation yang ditekankan oleh maskapai penerbangan AirAsia Indonesia terdapat pada headline dalam press release tanggal 20 Maret 2015. Adapun headline dalam press release tersebut adalah "AirAsia Umumkan Penutupan Operasi SAR QZ8501". Menurut Kriyantono (2008:130) judul berita (headline) merupakan tulisan yang pertama kali dibaca oleh khalayak atau pembaca. Sehingga berdasarkan hal tersebut judul berita harus dibuat semenarik mungkin. Selain itu, pada dasarnya judul berita merupakan cerminan dari isi berita yang ingin diangkat. Merujuk pada berbagai penjelasan tersebut tentunya menjelaskan bahwa intisari dari penyelesaian yang ditawarkan oleh maskapai penerbangan AirAsia Indonesia adalah penutupan upaya penanganan kasus kecelakaan pesawat QZ8501.

Tidak hanya itu, penguatan bingkai treatment recommendation yang ditawarkan oleh maskapai penerbangan AirAsia Indonesia terlihat jelaspada siaran press release tanggal 20 Maret 2015. Adapun dalam press release tersebut, maskapai penerbangan AirAsia Indonesia menuliskan terkait pernyataan Sunu Widyatmoko yang menjelaskan akan penutupan resmi Crisis Centre yang berada di ruang Mahameru, Markas Polisi Daerah (MAPOLDA) Jawa Timur serta pengaktifan pusat informasi bagi keluarga dan kerabat penumpang pesawat QZ8501.

Sunu Widyatmoko, Presiden Direktur AirAsia Indonesia menambahkan "Crisis Centre kami yang berada di
Ruang Mahameru, Markas Polisi Daerah (MAPOLDA) Jawa Timur secara resmi ditutup hari ini. AirAsia telah mengaktifkan pusat informasi bagi keluarga dan kerabat yang hendak memperoleh bantuan terkait pengurusan administrasi legal maupun informasi mengenai perkembangan hasil identifikasi." (Paragraf 5 Surabaya, 20 Maret 2015)

Melihat penutupan ruangan crisis centre tersebut tentu menjelaskan bahwa baik pihak maskapai penerbangan AirAsia Indonesia ataupun otoritas terkait tidak akan melanjutkan kembali upaya pencarian dan evakuasi. Sekalipun, pada kenyataannya upaya penanganan yang dilakukan oleh pihak maskapai bersama dengan otoritas terkait tersebut belum dikatakan selesai karena masih banyak penumpang pesawat QZ8501 yang belum tertemukan dan belum berhasil untuk diidentifikasi. Selain itu, penulisan yang menjelaskan pengurusan administrasi legal pada kutipan Sunu diatas menjadi penguat terakhir akan penyelesaian yang ingin ditekankan oleh pihak maskapai penerbangan AirAsia Indonesia.

\section{KESIMPULAN}

Berdasarkan hasil pembahasan yang telah dipaparkan, yakni terkait bingkai krisis QZ8501 pada press release AirAsia Indonesia yang dimuat dalam situs website www.qz8501.airasia.com. Peneliti menemukan bahwa frame besar yang dijadikan pijakan maskapai penerbangan AirAsia Indonesia dalam membingkai krisis QZ8501, 
adalah: krisis kecelakaan pesawat QZ8501 dianggap sebagai musibah yang menimpa maskapai penerbangan AirAsia Indonesia. Adapun hasil temuan akan frame krisis tersebut, peneliti temukan pada berbagai siaran press release yang dikelompokkan ke dalam tiga tahapan krisis, yakni: tahap precrisis, acute-crisis, dan pasca-crisis guna untuk mengatasi berbagai isu maupun opini negatif yang dibentuk oleh media massa.

Hasil frame krisis tersebut digunakan sebagai landasan maskapai penerbangan AirAsia Indonesia untuk mengalihkan berbagai isu, opini, maupun fakta negatif yang berkaitan dengan krisis tersebut, seperti halnya berbagai fakta yang menjelaskan bahwa terjadinya kecelakaan QZ8501 merupakan hasil dari kesalahan faktor internal, seperti: rusaknya beberapa komponen pesawat, maupun kesalahan dari crew (pilot dan co-pilot) yang bertugas .

Sehingga terlihat dengan jelas bagaimana fungsi press release yang sebagai alat untuk mengalihkan perhatian publik pada fakta yang merugikan organisasi dan memusatkan pada fakta yang menguntungkan organisasi.

Dari segi saran, secara garis besar dapat dijelaskan bahwa, penelitian analisa framing ini merupakan jenis penelitian yang hanya sebatas level teks. Mendapati hal tersebut, tentunya menunjukan bahwa penelitian ini hanya melibatkan unsur transaksional peneliti dengan teks, tanpa melibatkan unsur bagaimana teks itu dibuat (level konteks). Oleh karena itu, penelitian ini masih perlu disempurnakan dan sangat terbuka untuk dianalisa dengan penelitian metode studi kasus dengan melakukan wawancara kepada public relations terkait untuk mencari tahu mengenai bagaimana kebijakan dan faktor apa yang menjadi pertimbangan dalam penulisan press release. Selain itu, penelitian ini juga dapat disempurnakan melalui analisa framing pada media massa dengan isu yang sama. Hal ini perlu dilakukan agar praktisi public relations dapat melihat dan mengetahui bagaimana opini publik dan agenda setting yang terbentuk selama isu atau peristiwa sedang berlangsung.

\section{DAFTAR PUSTAKA}

Eriyanto. (2002). Analisis Framing: Konstruksi, Ideologi, dan Politik Media. Yogyakarta: PT LKiS Pelangi Aksara.

Eriyanto. (2011). Analisis Wacana: Pengantar Analisis Teks Media. Yogyakarta: PT LKiS Pelangi Aksara.

Kriyantono, Rachmat. (2006). Teknik Praktis Riset Komunikasi. Jakarta: Kencana Prenadamedia Group.

Kriyantono, Rachmat. (2008). Public Relations Writing: Teknik Produksi Media Public Relations dan 
Publisitas Korporat. Jakarta:

Kencana Prenadamedia Group.

Kriyantono, Rachmat. (2014). Teori Public Relations Perspektif Barat dan Lokal. Jakarta: Kencana Prenadamedia Group.

Kriyantono, Rachmat. (2015). Public Relations, Issue \& Crisis Management. Jakarta: Kencana Prenadamedia Group.

Sobur, Alex. (2015). Analisis Teks Media. Bandung: PT Remaja Rosdakarya.

\section{Jurnal:}

Harmonis. (2006). Jurnalistik Investigasi Dan Mengungkap Korupsi Melalui Media. Jurnal Komunikologi, 3(1), p. 7-13

Hallahan, Kirk. (1999). Seven Models of Framing: Implications for Public Relations. Journal of Public Relations Research, 11(3), p. 205242

Hartiana, Theresia Intan Putri. (2014). Citra Perusahaan Dalam Berita Krisis Perusahaan. Jurnal Kajian Komunikasi. 2, p.126-137

Poerwanto Eko dan Mauidzoh Uyuunul. (2016).Analisis Kecelakaan Penerbangan Di Indonesia Untuk Peningkatan Keselamatan Penerbangan. Jurnal Angkasa,8(2), p. $10-26$

Prastya, N. M. (2016). Analisis Framing Dalam Riset Public Relations. INFORMASI Kajian Ilmu Komunikasi. 46(2), p. 193-204
Purnama, F. Y., Nugraheni, Y., \& Andreas, S. (2016). Jurnalisme bencana dalam pemberitaan kecelakaan airasia qz8501 pada surat kabar jawa pos dan kompas. Jurnal Visi Komunikasi mercu buana jakarta, 15(1), 62-78

\section{Internet:}

www.qz8501.airasia.com, diakses pada tanggal 20 November 2017, 01.25 WIB

www.kbbi.web.id, diakses pada tanggal 20 Januari 2018 pk. 10.45 WIB

http://www.akademiasuransi.org/2015/04/actu al-total-loss-dan-constructive.html, diakses pada tanggal 20 November 2017, pk. 01.25 WIB

http://masyarakathukumudara.or.id/pengatura n-jam-terbang-pilot-dan-keselamatanpenerbangan-sipil/, diakses pada tanggal 20 Januari 2018, pk. 10.47 WIB

Maharani, Dian. (2014). Pasca Memahami Kondisi Psikis Keluarga Korban AirAsia. Diakses pada tanggal 20 November 2017, pk. 01.26 WIB dari

http://lifestyle.kompas.com/read/2014/12/31/1 23519823/Memahami.Kondisi.Psikis.Keluarg a.Korban.AirAsia

Pratomo, Harwanto B. (2014). 4 Dampak Hilangnya QZ8501 Bagi AirAsia. Diakses pada tanggal 20 November 2017, pk. 01.26 WIB dari

https://www.merdeka.com/uang/4-dampakhilangnya-pesawat-airasia-bagiperusahaan/kecelakaan-perdana-maskapaishock.html 